\title{
Factors Influencing to Behavioral Competency for Competitiveness and Success of Thai - Malaysia Border Trade Entrepreneurs to Support AEC
}

\author{
Nawit Amage (Corresponding author) \\ Faculty of Management Sciences, Prince of Songkla University \\ Hatyai Campus, Songkhla, Thailand \\ E-mail: abcohm@gmail.com \\ Idsaratt Rinthaisong \\ Faculty of Management Sciences, Prince of Songkla University \\ Hatyai Campus, Songkhla, Thailand \\ E-mail: idsaratt.r@psu.ac.th
}

\begin{abstract}
Anuwat Songsom
Faculty of Humanities and Social Sciences, Prince of Songkla University

Pattani Campus, Pattani, Thailand

E-mail: sanuwat52@gmail.com
\end{abstract}

Received: March 8, 2013

Accepted: April 28, 2014

Published: April 28, 2014

doi:10.5296/jmr.v6i2.5437

URL: http://dx.doi.org/10.5296/jmr.v6i2.5437

\begin{abstract}
The purpose of this study was to investigate factors related to behavioral competencies in order to develop a conceptual framework for competitiveness and success of Thai - Malaysia border trade entrepreneurs to support the ASEAN Economic Community (AEC). This study was conducted by using a literature review and document analysis. The results indicated that characteristics of entrepreneurs factor, transformational leadership factor, behavioral competencies factor and plan southern border provinces factor had a direct relationship with competitive advantage factor. Besides, characteristics of entrepreneurs factor,
\end{abstract}




\section{Macrothink}

Journal of Management Research ISSN 1941-899X

2014, Vol. 6, No. 2

transformational leadership factor and plan southern border provinces factor had an indirect relationship with competitive advantage factor through behavioral competencies factor. AEC blueprint factor had an indirect relationship with competitive advantage factor through plan southern border provinces factor. And competitive advantage factor had a direct relationship with successful factor.

Keyword: Behavioral competencies, Transformational leadership, Competitive advantage, Successful 


\section{Introduction}

Border trade is an economic activity that is very important to the overall economy of Thailand. Thailand has borders with four neighbor countries; Myanmar, Laos, Cambodia and Malaysia. In 2013, Thailand is border trade was valued at 924,241.79 million baht. Malaysia is the biggest value border trade of Thailand. By border trade between Thailand-Malaysia was valued at 501,401.99 million baht equal $54.25 \%$ of border trade. Trade between Thailand-Myanmar was valued at 196,866.33 million baht equal $21.30 \%$ of border trade. Trade between ThailandLaos was valued at 132,137.16 million baht equal $14.30 \%$ of border trade. And trade between Thailand- Cambodia was valued at 93,836.31 million baht equal $10.15 \%$ of border trade.

The economies of the five southern border provinces need to develop a network of special areas to improve linkages with international maritime transport. The southern border provinces have the advantage of proximity to the Gulf of Thailand and Andaman Sea and are thus able to transport via land, rail and sea. There is a great opportunity to develop cooperation with Malaysia, particularly in the Northern Corridor Economic Region (NCER), East Coast Economic Region (ECER) and in the $10^{\text {th }}$ National development plan of Malaysia for the years 2011-2015.

With the economic liberalization in the ASEAN Economic Community due to begin in 2015, the trade between Thai - Malaysian entrepreneurs will have to contend with border competition. The liberalization of trade in services in ASEAN under the ASEAN Framework Agreement on Services (AFAS) will reduce and remove regulations that impede trade in services between all sectors of ASEAN, under what is called the AEC blueprint. It has an impact on Thai-Malaysian border trade in terms of logistics management, consulting services, transportation, and trade through local businesses in all in members of ASEAN. The situation will change according to conditions and the trade of the ASEAN Economic Community (AEC).

Thai-Malaysia border trade entrepreneurs have to understand and learn how to adapt to the AEC Blueprint to create a competitive advantage. It is therefore necessary to develop the capacity of entrepreneurs to be ready for change. The problem needs a solution and the most effective way to develop the competencies necessary for the Thai-Malaysian border trade is to enhance the knowledge, skills and attributes necessary for the management of enterprises. That will lead to improved competency. This is added urgency because the trade along the Thai Malaysian border will be opened up fully in the year 2015.

\section{Objectives}

The objective of this research is to identify the key factors that will impact on the trade along the Thailand - Malaysia border under the AEC. And to identify the causal structure of the elements that influence to behavioral competency for competitiveness and success of Thai Malaysia border trade entrepreneurs to support AEC.

\section{Research Methodology}

The research approach is Documentary Research using secondary data of documents and studies related to the question, to analyze and synthesize the information to identify the 
structural causal elements that influence to behavioral competency for competitiveness and success of Thai - Malaysia border trade entrepreneurs to support AEC.

\section{Literature Review}

The research aim to build a conceptual framework is based on the theory of the concept of the entrepreneur. The border trade entrepreneurs have to be talented and need smart leadership (Lewin, Lippitt \& White, 1939) for their people to manage their own affairs in order to bring businesses into the circumstances of intense competition in the future (Likert \& Bowerts,1973) when they are open to free trade within ASEAN in the year 2015.

\subsection{Character entrepreneur}

Character entrepreneur, leadership motivation and communication interact and influence decision making, quality control and performance goals. Blake and Mouton (1964) found the quality and the relationship of leadership influence people and production factors. On the other hand, Fiedler (1978) has shown that leadership can be effective or ineffective depending on the situation, the relationship between the leader and followers, and the structure of the work. Leaders should have a way to motivate their followers to achieve the expected outcomes (Burns, 1978) by setting clear requirements and providing rewards in exchange for trying to achieve business goals. This exchange will foster staff satisfaction in working together to achieve the goals of the work (Bass, 1985). Leadership-oriented goals enable a high-performance environment that is relatively stable. Tate (2009) studied how the owner can change the environment for small business in England, and found that the characteristics of leaders, including individual personality was key. Thai - Malaysian entrepreneurs have to learn and develop leadership skills (Singh \& Vohra, 2009) to communicate, interact with colleagues, customers and partners, leadership skills which include the ability to make decisions for the right target, quality control, performance goals and the ability to adapt the environment within the organization to support external factors (Dess, Lumpkin \& Covin,1998).

\subsection{Transformational Leadership}

Transformational Leadership are a class of behavioral theory that contend that there is no one best way of organizing / leading and that an organizational / leadership style that is effective in some situations may not be successful in others (Fiedler, 1964). In other words: The optimal organization / leadership style is contingent upon various internal and external constraints. There are also contingency theories that relate to decision making (Vroom \& Yetton, 1973). According to these models, the effectiveness of a decision procedure depends upon a number of aspects of the situation: the importance of the decision quality and acceptance; the amount of relevant information possessed by the leader and subordinates; the likelihood that subordinates will accept an autocratic decision or cooperate in trying to make a good decision if allowed to participate; the amount of disagreement among subordinates with respect to their preferred alternatives.

\subsection{AEC Blueprint}

Border trade in Europe has had to adapt to multiple national cultures by decreasing the influence of different environments to develop competency skills, understanding the behaviour of consumers from different countries to create opportunities and increase the commercial 
value of the border trade (Muzychenko, 2008). The cross-border trade should improve competencies to fit the environment, and management of different institutions throughout the European Union (Perkmann, 2005). Border trade in the United States needs to create a single market like Europe by increased cooperation with foreign partners (Meunier \& Nicolaidis, 2005). Following the integration of the member countries of ASEAN, like the EU (Ahmad, 2007), economic cooperation including trade along the Thai - Malaysia border should be adjusted in the same way as the border trade within the EU to be ready to face increased cooperation with foreign partners (Meunier \& Nicolaidis, 2005), and to improve knowledge, in the context of understanding the diversity of cultures and the needs of consumers in both countries. Some may have to cooperate with partners from those countries. Mitchell et al. (1970) analyze the situation from a management-oriented approach to the theory. Administrative procedures or methods are best. This selection is used to fit the situation. Strube and Garcia (1981) analyze a situation-oriented leadership and management efficiency. The application of the theory is attributed to experience. Ayman, Chemers and Fiedler (1995) provide a model of leadership as characterising a person who learns how to delegate his power to employees. According to a review by the Blue House (Luthans,1973), the traditional management system has been replaced with a behavioural management system and procedures. In actual practice, not just any theory can be applied to every organization and management problem. Management should be flexible and adaptable to situations. Fernadez and Saberwal (2001) have studied knowledge management by the administration of the situation. It can be concluded that the trade along the Thai - Malaysia border can be managed by the operator's application of knowledge and has ability to work flexibly, and to adapt to the situation of unrest in three southern provinces. Liberalization of trade under competitive conditions ensures that the rules of AEC will be followed.

\subsection{Behavioral competencies}

Behavioral competencies are related to entrepreneurship (Li, Huang \& Tsai, 2009), namely the ability to create business opportunities, competency evaluation of business opportunities, competency of the network business, ability to identify and resolve problems, and the ability to communicate. Hellriegel, Jackson and Slocum (2008) claim that managers should have competency in management capabilities, including communications, planning and performance management, ability to work as a team, tactical missions, cultural competency and understanding between nations, and self-control. Mitchelmore and Rowley (2010) measure competency by taking into account competency on an individual level, competency as a trader, business intelligence and competency management, competency skills and relationships. Ahmad et al. (2010) undertake a competency analysis to study the background of entrepreneur personal characteristics, including appearance, attitude, people in their own image, and social role. Competency characteristics are hidden within the individual. Leadership can encourage competency in the individual (McClelland, 1973). The criteria are set out in an individual's job responsibilities namely the elements of the competency of skills, knowledge, attitudes, values and opinions about their own image. Knowledge involves power, motivation, habits and self-image. The role of social skills within the individual drives people to work effectively (Boyatzis, 1982). A strong employer-employees relationship is the criterion for maximum 
operational efficiency (Spencer \& Spencer, 1993). Competency characteristics of the individual, knowledge, motivation, habit, self-image, social roles and skills can lead to the growth and survival of the business (Bird, 1995). Competency skills include understanding the competency concept, competency of the organization, competency strategies and organizational commitment (Mulder, et al., 2007). The entrepreneur needs competency to create opportunities, relationships, performance and organizational competency strategies, as well as competency in human resource management. Izquierdo and Deshoolmeester (2005) have researched the competency of operators in the view of scholars and entrepreneurs.

\subsection{Thai SMEs Plan (2012-2016)}

Small and Medium Enterprises Promotion Plan No. 3 (2012-2016) aims to promote entrepreneurship, by increasing the number of small and medium enterprises registered as legal persons by 250,000 in 2016 to build capacity, of depth to the AEC. For small and medium-sized enterprises, a target of 30,000 by the year 2016 aims to develop small and medium enterprises with annual improvement and environmental factors in the business to facilitate the implementation of small and medium-sized enterprises. Management and promotion of small and medium enterprises has to be more efficient for functional integration for AEC (ASEAN Strategic Action Plan for SME Development (2010-2015)). According to the Office of the Strategic Southern Border Provinces (Copyright 2010-2013, revised in 2011), there are plans to develop the southern border provinces, which covers the five provinces of Pattani, Yala, Narathiwat, Songkhla and Satun. It explains there are strategic issues that must be examined urgently, which include supporting the manufacturing sector to entitle it to operate normally (Tseng, 2012), by trying to reduce the unrest in the area to less than five percent to improve the security and safety of the product, promote tourism, and border trade (Man, Lau \& Chan, 2002). The market needs development of production technology, and capacity management, both internally and for export (Indarti \& Langenberg,2004). The aim of management should be to effectively reach the market. It needs knowledge to create value-added products, such as Halal food standards, in recognition of the global market. International transport links and the development of process technology are needed to create value-added rubber for the creation of rubber production in the southern border provinces (Possion et al., 2002). Promotion, management, marketing and transportation are also necessary (Islam et al.,2011). The performance of border trade requires an analysis of the situation. According to the Small and Medium Enterprises Promotion Plan No. 3 (2012-2016), it is the correlation structure of all these causal factors that influence and impact both directly and indirectly on the performance of the trade along the Thai - Malaysian border for the ASEAN Economic Community.

\subsection{Competitiveness}

Competitiveness is direct influenced to business. Factors influencing the growth of small and medium enterprises in Vietnam is to make a difference finance policy and customer response satisfaction (Nguyen., et al., 2009) The ability to be an entrepreneur in the business opportunity. Relationships, concepts, organizational ability to define a strategy for business competitiveness and engagement organization. Performance of the sales growth. Cash return on sales, return on 


\section{Macrothink}

Journal of Management Research

ISSN 1941-899X

2014, Vol. 6, No. 2

investment, earnings growth and market share (Li, 2009). Resources and competencies are correlated with their ability to competitiveness and contributes to a sustainable competitive advantage. Resources and competencies to create value for the business than the competitors. As a result, competitors cannot imitate strategies to create the same interests or values.Thus contributes to the sustainable competitiveness (Barreto, 2010).

\subsection{Success in entrepreneurship}

Success in entrepreneurship is considered success in business performance involving financial rate of return on the investment growth compared to last year. Percentage growth in sales compared to last year. And percentage market share compared to last year. Consistent with studies of Man, Lau and Snape (2008), Nguyen et al. (2009), Lee (2007), Wittmann, Hunt and Arnett (2009), Zeng, Xie and Tam (2010), Ziggers and Tjemkes (2010), Feng, Sun and Zhang (2010).

The result of this research is a conceptual framework to study the correlation structure of the causal factors that influence and impact to behavioral competency for competitiveness and success of Thai - Malaysia border trade entrepreneurs to support AEC. This hypothesis can be summarized as follows:

1) Character entrepreneur influence to Behavioral competencies.

2) Character entrepreneur influence to Competitiveness.

3) Transformational Leadership influence to Behavioral competencies.

4) Transformational Leadership influence to Competitiveness.

5) AEC blueprint influence to Thailand SMEs Plan (2012-2016).

6) Thailand SMEs Plan (2012-2016) influence to Behavioral competencies.

7) Thailand SMEs Plan (2012-2016) influence to Competitiveness.

8) Behavioral competencies influence to Competitiveness.

9) Competitiveness influence to Success in entrepreneurship.

The Conceptual Framework needs further empirical studies to academically establish the impact of each antecedent variable toward both types of performance and impact to behavioral competency for competitiveness and success of Thai - Malaysia border trade entrepreneurs to support AEC as shown in figure 1. 


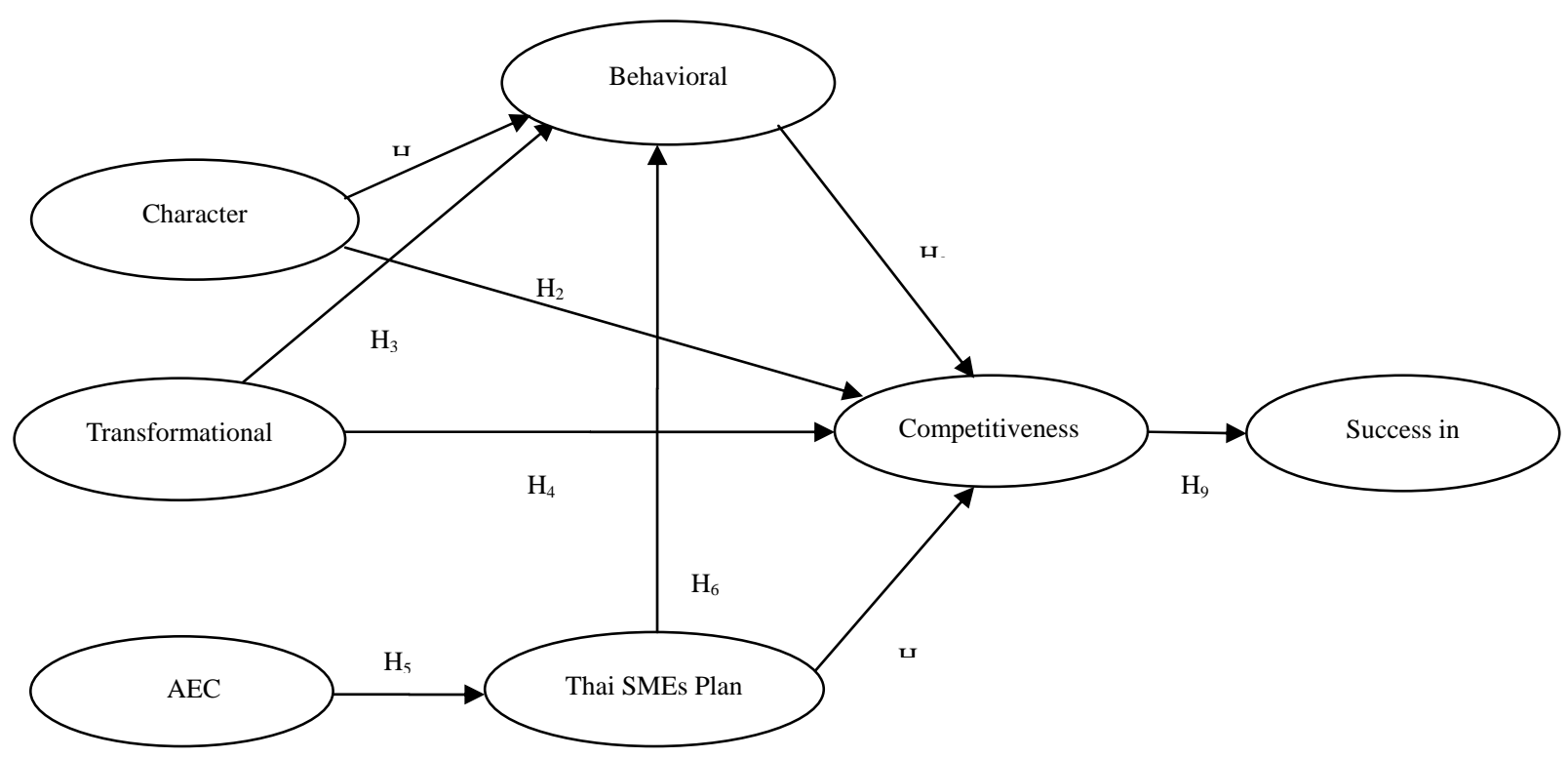

Figure 1. Conceptual Framework

\section{Acknowledgement}

The author wish to express special thank to Dr. Idsaratt Rinthaisong and Asst.Prof.Dr.Anuwat Songsom who recommends this paper and also to thank the Office of the Higher Education Commission, Thailand for supporting by grant fund under the program strategic scholarships fellowships frontier research networks (specific for southern region).

\section{References}

Ahmad, N. H. (2007). A Cross cultural study of entrepreneurial competencies and entrepreneurial success in SMEs in Australia and Malaysia. Ph.D. Dissertation, University of Adelaide. Australia.

Ahmad, N. H., Ramayah, T., Wilson, C., \& Kummerow, L. (2010). Is entrepreneurial competency and business success relationship contingent upon business environment?: A study of Malaysian SMEs. International Journal of Entrepreneurial Behavior \& Research, 16(3), 182-203. http://dx.doi.org/10.1108/13552551011042780

Ayman, R., Chemers, M.M., \& Fiedler, F. (1995). The contingency model of leadership effectiveness: Its levels of analysis. The Leadership Quarterly, 6(2), 147-167. http://dx.doi.org/10.1016/1048-9843(95)90032-2

Barreto, I. (2010). Dynamic capabilities: A review of past research and an agenda for the future. Journal of Management, 36(1), 256-280. http://dx.doi.org/10.1177/0149206309350776

Bass, B. M. (1985). Leadership: Good, better, best. Organizational Dynamics, 13(3), 26-40. http://dx.doi.org/10.1016/0090-2616(85)90028-2 
Blake, R. R., \& Mouton, J. S. (1964). The Managerial Grid. Houston: Gulf Publishing Company.

Bird, B. J. (1995). The towards a theory of entrepreneurial competency. In J.A. Katz and R. H. Brockhaus (Eds), Advances in entrepreneurship, firm emergence, and growth (pp. 51-72). Greenwich, CT: Jai Press.

Boyatzis, R. E. (1982). The competent manager: A model for effective performance. New York: John Wiley \& Son.

Burns, J.M. (1978). Leadership. New York: Harper \& Row.

Dess, G.G., Lumpkin, G.T. \& Covin, J. G. (1998). Entrepreneurial strategy making and firm performance: Tests of contingency and configurational models. Strategic management journal, 18(9), 677-695.

Feng, T., Sun, L., \& Zhang, Y. (2010). The effects of customer and supplier involvement on competitive advantage: An empirical study in China. Industrial Marketing Management, 39(8), 1384-1394. http://dx.doi.org/10.1016/j.indmarman.2010.04.006

Fernadez, I. B. \& Saberwal. R. (2001). Organizational knowledge management: A contingency perspective. Journal of Management Information Systems, 18(1), 23-55.

Fiedler, F. E. (1964). A contingency model of leadership effectiveness. In L. Berkowitz (Ed.), Advances in Experimental Social Psychology (pp. 149-190). New York: Academic Press.

Fiedler, F.E. (1978). The contingency model and the dynamics of the leadership process. Advances in Experimental Social Psychology, 11, 59-112. http://dx.doi.org/10.1016/S0065-2601(08)60005-2

Hellriegel, D., Jackson, S. E. \& Slocum, J. W. (2008). Management: A competency-based Approach. Ohio: South-Western College Publisher.

Indarti, N. \& Langenberg, M. (2004). Factors affecting business success among SMEs: empirical evidences from Indonesia. Retrieved from www.utwente.nl/mb/nikos/archief/esu2004/papers/indartilangenberg.pdf

Islam, M. A., Khan, M.A., Obaidullah, A. Z. M., \& Alam, M.S. (2011). Effect of entrepreneur and firm characteristics on the business success of small and medium enterprises (SMEs) in Bangladesh. International Journal of Business and Management, 6(3), 289-299.

Izquierdo, E. \& Deshoolmeester, D. (2005). The importance of competencies for entrepreneurship: A view from entrepreneurs and scholars' perspective. Retrieved from www.espae.espol

Lee, C. W. (2007). Strategic alliance influence on small and medium firm performance. Journal of Business Research, 60, 731-741. http://dx.doi.org/10.1016/j.jbusres.2007.02.018 
Lewin, K., Lippitt, R., \& White, R. K. (1939). Patterns of aggressive behavior in experimentally created "social climates". Journal of Social Psychology, 10, 271-299. http://dx.doi.org/10.1080/00224545.1939.9713366

Likert, R. \& Bowerts, D. G. (1973). Improving the accuracy of P/L reports by estimating the change in dollar value of the human organization. Michigan Business Review, 25(2), 15-24.

Li, X. (2009). Entrepreneurial competencies as an entrepreneurial distinctive: An examination of the competency approach in defining entrepreneurs. Master Thesis. Singapore Management University. Singapore.

Li, Y.H., Huang, J.W. \& Tsai, M.T. (2009). Entrepreneurial orientation and firm performance: The role of knowledge creation process. Industrial Marketing Management, 38, 440-449. http://dx.doi.org/10.1016/j.indmarman.2008.02.004

Luthans, F. (1973). The contingency theory of management: A path out of the jungle. Business Horizons, 16(3), 67-72. http://dx.doi.org/10.1016/0007-6813(73)90026-8

Man, T.W.Y., Lau, T. \& Snape, E. (2008). Entrepreneurial competencies and the performance of small and medium enterprises: An investigation through a framework of competitiveness. Journal of Small Business and Entrepreneurship, 23(3), 257-276. http://dx.doi.org/10.1080/08276331.2008.10593424

Man, T. W. Y., Lau, T., \& Chan, K. F. (2002). The competitiveness of small and medium enterprises: A conceptualization with focus on entrepreneurial competencies. Journal of Business Venturing, 17(2), 123-142. http://dx.doi.org/10.1016/S0883-9026(00)00058-6

McClelland, D. C. (1973). Testing for competence rather than for intelligence. American Psychologist, 28(1), 1-14. http://dx.doi.org/10.1037/h0034092

Meunier, S. \& Nicolaidis, K. (2005) The European Union as a trade power. In Proceedings of Archive of European Integration (AEI). Texas: USA.

Mitchell T.R., Biglan, A., Oncken, G.R., \& Fiedler, F.E. (1970). The contingency model: Criticism and suggestions. The Academy of Management Journal, 13(3), 253-267. http://dx.doi.org/10.2307/254963

Mitchelmore, S., \& Rowley, J. (2010). Entrepreneurial competencies: A literature review and development agenda. International Journal of Entrepreneurial Behavior \& Research, 16(2), 92 -111. http://dx.doi.org/10.1108/13552551011026995

Mulder, M., Lans, T., Verstegen, J., Biemans, H. \& Meijer, Y. (2007). Competence development of entrepreneurs in innovative horticulture. Journal of Workplace Learning, 19(1), 32 - 44. http://dx.doi.org/10.1108/13665620710719330

Muzychenko, O. (2008). Cross-cultural entrepreneurial competence in Identifying international business opportunities. European Management Journal, 26(6), 366-377. http://dx.doi.org/10.1016/j.emj.2008.09.002 
Nguyen, T. H., Alam, Q., Perry, M. \& Prajogo, D. (2009).The Entrepreneurial role of the state and SME growth in Vietnam, JOAAG. 4(1), 60-71.

Perkmann, M. (2005). Cross-border co-operation as policy entrepreneurship: explaining the variable success of European cross-border regions. Centre for the Study of Globalisation and Regionalisation.

Possion, R., Su, Z., Amboise, D. \& Gasse, Y. (2002). Success factors for small and medium-sized Canadian enterprises doing business in emerging Asian markets. In Proceeding of International Council for Small Business $47^{\text {th }}$ World Conference. San Juan, Puerto Rico.

Singh, M. \& Vohra, N. (2009). Level of formalisation of human resource management in small and medium enterprises in India. The Journal of Entrepreneurship, 18(1), 95-116. http://dx.doi.org/10.1177/097135570801800105

Spencer, L.M. \& Spencer, S.M. (1993). Competence at work: Models for superior Performance. New York: John Wiley \& Sons.

Strube, M. J. \& Garcia, J. E. (1981). A meta-analytic investigation of Fiedler's contingency model of leadership effectiveness. Psychological Bulletin, 90(2), 307-321. http://dx.doi.org/10.1037/0033-2909.90.2.307

Tate, G. (2009). Entrepreneurship and the environment for rural SMEs in the Shropshire Hills, UK, 1997-2009. The Journal of Entrepreneurship, 19(2), 191-207. http://dx.doi.org//10.1177/097135571001900206

Tseng, C.C. (2012). Linking entrepreneurial infrastructures and new business development entrepreneurship development in Taiwan. The Journal of Entrepreneurship, 21(1), 117-132. http://dx.doi.org/10.1177/097135571102100105

Vroom, V.H. \& Yetton, P.W. (1973). Leadership and decision-making. Pittsburgh: University of Pittsburgh Press.

Wittmann, C.M., Hunt, S.D., \& Arnett. D.B. (2009). Explaining alliance success: Competences, resources. Relational factors, and resource-advantage theory. Industrial Marketing Management, 38(7), 743-756. http://dx.doi.org/10.1016/j.indmarman.2008.02.007

Zeng, S. X., Xie, X. M., \& Tam, C. M. (2010). Relationship between cooperation networks and innovation performance of MEs. Technovation, 30(30), 181-194. http://dx.doi.org/10.1016/j.technovation.2009.08.003

Ziggers,G.W., \& Tjemkes, B. (2010). Dynamics in inter-firm collaboration: The impact of alliance capabilities on performance. Inetrnational Journal Food System Dynamics, 2, 151-166. 